\title{
A ROTULAGEM DE ALIMENTOS TRANSGÊNICOS NO ÂMBITO DO CONGRESSO NACIONAL E AS CONSEQUENCIAS AO CONSUMIDOR, ÀS PEQUENAS EMPRESAS E PEQUENOS PRODUTORES
}

\author{
THE LABELING OF TRANSGENIC FOODS IN THE CONTEXT OF THE \\ NATIONAL CONGRESS AND THE CONSEQUENCES TO CONSUMERS
} AND SMALL ENTERPRISES AND PRODUCERS

VALMIR CÉSAR POZZETTI ${ }^{1}$ REBECCA LUCAS CAMILO SUANO LOUREIRO JOÃO FERNANDES CARNEIRO JÚNIOR ${ }^{3}$

\section{RESUMO}

Esta pesquisa teve como objetivo analisar os pareceres legislativos referente à proposta de alteração da Lei de n. 11.105/2005 (Lei de Biossegurança) que conforma o Projeto de Lei ọ 34/2015 da Câmara dos Deputados, examinando os fundamentos usados pelos relatores na Comissão de Agricultura e Reforma Agrária (CRA), na Comissão de Meio Ambiente (CMA), na Comissão de Ciência, Tecnologia, Inovação, Comunicação e Informática (CCT) e na Comissão de Assuntos Sociais (CAS) - todas no âmbito do Senado Federal. Como objetivo complementar, buscou identificar, de um lado, as possíveis consequências dessa alteração legislativa às empresas de biotecnologia, aos pequenos produtores e pequenos empresários e,

\footnotetext{
${ }^{1}$ Doutor em Biodireito pela Université de Limoges/França. Professor Adjunto do Programa de Mestrado em Direito Ambiental da UEA - Universidade do Estado do Amazonas e Prof. Adjunto do Programa de Mestrado e Doutorado em Ciências Ambientais e Sustentabilidade da Amazônia da UFAM - Universidade Federal do Amazonas.. E-mail: v_pozzetti@ hotmail.com

${ }^{2}$ Mestranda em Direito Ambiental pela Universidade do Estado do Amazonas. Pós-graduada em Direito Público pela Universidade do Sul da Santa Catarina - UNISUL. Pós-graduanda em Direito Notarial e Registral pela Universidade Damásio. Manaus-AM. E-mail: rsuano@gmail.com

${ }^{3}$ Mestrando em Direito Ambiental pela Universidade do Estado do Amazonas. Pós-graduado em Direito Constitucional pela Universidade Anhanguera. Professor universitário e advogado. Manaus-AM. E-mail: juri.carneiro@gmail.com
} 
de outro, as potenciais violações aos direitos dos consumidores. A conclusão a que chegou foi a de que a propositura desprestigia o direito constitucional da informação e o princípio da precaução. Em relação ao primeiro, conforme os termos da proposta, o consumidor de alimentos não será comunicado da eventual presença de organismos geneticamente modificados, caso estes perfaçam menos de 1 (um) por cento da composição total do produto; além disso, não receberá informações que se esperariam amplas e adequadas nos rótulos dos alimentos cuja composição apresente concentração superior àquele limite, não lhe restando condições reais para uma escolha madura quanto ao consumo desses alimentos. Quanto à ausência de precaução, não existe análise científica conclusiva sobre os impactos dos alimentos geneticamente modificados, sejam eles danosos ou benéficos, na saúde dos seres humanos; acrescente-se o fato de a transgenia ter diferentes alcances e consequências biológicas, a depender de quem ingere o alimento, razão pela qual se torna ainda mais importante que o consumidor tenha a possibilidade de escolher, conscientemente, os produtos alimentícios que possam conter transgênicos. A pesquisa também chega à conclusão de que é inócua e ineficaz a proposta legal que faculta ao pequeno agricultor e ao pequeno empresário mencionarem a não utilização de organismos geneticamente modificados em seus produtos, uma vez que a análise necessária para comprovação da composição do alimento produzido gera custos que são repassados ao consumidor, violando a livre concorrência. A metodologia utilizada, quanto aos meios, foi a dos métodos dedutivo e descritivo, por meio de análise doutrinária, bibliográfica e legal. Quanto aos fins, a pesquisa foi qualitativa.

PALAVRA-CHAVE: Alteração legislativa; Direito do consumidor; Princípio da informação; Rotulagem; Transgênicos.

\begin{abstract}
This research had the objective of analyzing the legislative opinions regarding the proposed amendment of Law no. 11.105 / 2005 (Biosafety Law) that conforms the Draft Law ${ }^{\circ}$ (CRA), the Committee on the Environment (CMA), the Committee on Science, Technology, Innovation, Communication and Information Technology (CCT) and in the Committee on Social Affairs (CAS) - all within the scope of the Federal Senate. As a complementary objective, it sought to identify, on the one hand, the possible consequences of this legislative change to biotechnology companies, small producers and small businessmen and, on the other
\end{abstract}


hand, potential violations of consumer rights. The conclusion reached was that the proposal deprecates the constitutional right of information and the precautionary principle. As regards the first, according to the terms of the proposal, the food consumer will not be informed of the possible presence of genetically modified organisms if they are less than $1 \%$ of the total composition of the product; in addition, it will not receive information that would be expected to be broad and adequate on food labels whose composition has a concentration higher than that limit, leaving no real conditions for a mature choice as to the consumption of these foods. Regarding the lack of precaution, there is no conclusive scientific analysis on the impacts of genetically modified foods, whether harmful or beneficial, on human health; it should be added that transgenics have different biological consequences and consequences, depending on who ingests the food, which is why it is even more important for the consumer to be able to consciously choose foodstuffs that may contain transgenics. The research also concludes that the legal proposal that allows the small farmer and the small business owner to mention the non-use of genetically modified organisms in their products is innocuous and ineffective, since the analysis necessary to prove the composition of the food produced generates costs that are passed on to the consumer, violating free competition. The methodology used, as far as the means, was of the deductive and descriptive methods, through doctrinal, bibliographical and legal analysis. As for the purposes, the research was qualitative.

KEYWORDS: Legislative change; Consumer law; Principle of information; Labeling; Transgenic.

\section{INTRODUÇÃO}

A problemática que envolve a rotulagem dos alimentos transgênicos se baseia na necessidade de se proteger os direitos dos consumidores constitucionalmente previstos (direito à informação) e de se possibilitar ao consumidor que seja realizada uma escolha consciente relacionada aos alimentos que irá consumir.

Inobstante a esses mandamentos, o Deputado Federal Luís Carlos Heinze apresentou a Proposta de Lei da Câmara - PLC n ${ }^{\circ}$ 34/2015, sugerindo a alteração do art. 40 da Lei $n^{\circ}$ 11.105/2005 - Lei de Biossegurança. Se aprovada a proposta, passará a ser obrigatório constar dos rótulos dos alimentos a informação de serem produzidos a partir de Organismos Geneticamente Modificados - OGM's ou derivados, apenas se houver presença superior a $1 \%$ 
(um por cento) de produtos transgênicos em sua composição final, detectada em análise específica.

Diante desse quadro, as empresas estarão respaldadas a omitir informações importantes sobre a composição dos alimentos produzidos com matéria-prima transgênica. Além disso, haverá a possibilidade de o consumidor ser induzido a erro sobre estar consumindo produto não transgênico, quando, na realidade, a matéria prima utilizada para a sua fabricação era OGM.

$\mathrm{O}$ projeto visa ainda a retirar o símbolo "T" (que identifica o produto como Transgênico), que referencia os alimentos transgênicos como tal, nas embalagens dos produtos que chegarão ao alcance do consumidor. Dessa forma, sem essa informação nos rótulos, o consumidor deixa de exercer o seu direito de escolha, vez que que não tem conhecimento se o alimento é ou não, transgênico.

É pertinente salientar que o direito à informação do consumidor é direito previsto constitucionalmente, independentemente de existir possibilidade de o produto oferecido gerar riscos à saúde

Por fim, a proposta visa impor que, ao contrário, os produtores de alimentos não transgênicos que façam constar a informação nos rótulos de seus produtos por meio de análise específica. Entretanto, esta análise, ainda não está discriminada em norma.

Assim, a problemática que envolve essa pesquisa é: "quais os argumentos defendidos nas comissões do Senado Federal para a aprovação ou rejeição do PLC n ${ }^{\circ}$ 34/2015 e quais as possíveis consequências que a referida alteração poderá ocasionar às pequenas empresas, aos pequenos produtores rurais, aos consumidores, especialmente no que se refere aos princípios da informação, da precaução e da livre concorrência?

A temática abordada neste trabalho se justifica tendo em vista que há necessidade de se discutir os possíveis reflexos da alteração legislativa anteriormente de sua concretização, evitando-se a aprovação de leis que prejudiquem os direitos fundamentais da população.

\section{OBJETIVOS}

Esta pesquisa possui como objetivo geral analisar os pareceres emitidos pelas Comissões do Senado Federal durante a tramitação do projeto de Lei da Câmara no 34/2015, que altera a Lei ${ }^{\circ} 11.105 / 2005$, Lei de Biossegurança. 
Especificamente, busca-se relacionar os argumentos levantados por cada uma das comissões de forma que sejam identificadas as informações favoráveis e as informações contrárias abordadas.

Por fim, objetiva-se identificar quais as possíveis consequências que a referida alteração poderia ocasionar às pequenas empresas e aos pequenos produtores e quais os direitos dos consumidores seriam violados, especialmente no que se refere aos princípios da informação, da precaução e da livre concorrência.

\section{METODOLOGIA}

A metodologia utilizada nesta pesquisa, quanto aos meios, o método dedutivo e descritivo. Nos dizeres de Bittar (2019, p.35), o método dedutivo "corresponde à extração discursiva do conhecimento a partir de premissas gerais aplicáveis a hipóteses concretas". Ainda nesse sentido, Pradanov e Freitas (2013, p. 27) mencionam:

\footnotetext{
O método dedutivo, de acordo com o entendimento clássico, é o método que parte do geral e, a seguir, desce ao particular. A partir de princípios, leis ou teorias consideradas verdadeiras e indiscutíveis, prediz a ocorrência de casos particulares com base na lógica.
}

Foi realizada análise doutrinária, bibliográfica e legal, uma vez que os conceitos mencionados derivam em grande parte das próprias normas, incluindo-se aqui, a Constituição Federal, a Lei de Biossegurança e a Resolução no 259/2012 da Agência Nacional de Vigilância Sanitária (ANVISA).

Quanto aos fins, a pesquisa foi qualitativa, em virtude da necessidade de verificar, interpretar, analisar, compreender e explicar as consequências da aprovação do PLC n 34/2015, conforme se depreende dos ensinamentos de Pradanov e Freitas (2013, p. 70):

Pesquisa qualitativa: considera que há uma relação dinâmica entre o mundo real e o sujeito, isto é, um vínculo indissociável entre o mundo objetivo e a subjetividade do sujeito que não pode ser traduzido em números. A interpretação dos fenômenos e a atribuição de significados são básicas no processo de pesquisa qualitativa. Esta não requer o uso de métodos e técnicas estatísticas. O ambiente natural é a fonte direta para coleta de dados e o pesquisador é o instrumento-chave. Tal pesquisa é descritiva. Os pesquisadores tendem a analisar seus dados indutivamente. O processo e seu significado são os focos principais de abordagem.

\section{DESENVOLVIMENTO}




\title{
1 BREVE HISTÓRICO DA TRAMITAÇÃO DO PROJETO DE LEI No 34/2015
}

A questão que envolve a produção de alimentos transgênicos é muito polêmica, vez que envolve não somente a segurança alimentar, mas também, a segurança ambiental.

Nesse sentido destacam Pozzetti e Campos (2017, p. 253):

\begin{abstract}
A busca desenfreada pelo lucro tem trazido externalidades negativas ao meio ambiente. $\mathrm{O}$ homem contemporâneo tem sido negligente ao estimular o consumo exagerado, causando destruição do meio ambiente natural, modificando sistematicamente espaços naturais, sem recuperá-los e, com isso, gerando reflexos negativos tais como; aquecimento global, diminuição da camada de ozônio, mudanças climáticas, inexistência de espaços verdes urbanos, tempestades, e outros.
\end{abstract}

Iniciado pelo Deputado Federal Luís Carlos Heinze, o Projeto de Lei da Câmara (PLC) $n^{\circ} 34 / 2015$, tem como proposta alterar o artigo 40 da Lei $n^{\circ} 11.105 / 2005$ (Lei de Biossegurança). Atualmente, o texto legal dispõe que:

Art. 40 Os alimentos e ingredientes alimentares destinados ao consumo humano ou animal que contenham ou sejam produzidos a partir de OGM ou derivados deverão conter informação nesse sentido em seus rótulos, conforme regulamento.

Se aprovada a mudança, o artigo 40 passará a ter a seguinte redação:

Art. 40. Os rótulos dos alimentos e dos ingredientes alimentares destinados ao
consumo humano ou animal, oferecidos em embalagem de consumo final, que
contenham ou sejam produzidos a partir de OGM ou derivados com presença superior
a $1 \%$ (um por cento) de sua composição final, detectada em análise específica,
conforme regulamento, deverão informar ao consumidor a natureza transgênica do
alimento.§ 1o A informação estabelecida neste artigo deve constar nos rótulos dos
alimentos embalados na ausência do consumidor, bem como nos recipientes de
alimentos vendidos a granel ou in natura diretamente ao consumidor, devendo ser
grafada, em destaque, de forma legível, utilizando-se uma das seguintes expressões,
conforme o caso, "(nome do produto) transgênico" ou "contém (nome do ingrediente)
transgênico". § 20 Aos alimentos que não contenham organismos geneticamente
modificados será facultada a rotulagem "livre de transgênicos", comprovada a total
ausência no alimento de organismos geneticamente modificados, por meio de análise
específica. § 30 A informação de que trata o § 1o deverá atender ao tamanho mínimo
de letra definida no Regulamento Técnico de Rotulagem Geral de Alimentos
Embalados.

O PLC no 34/2015 foi encaminhado para o Senado Federal em 30 de abril de 2015.

Em 05 de maio de 2015, foi distribuído à Comissão de Assuntos Sociais (CAS), sendo encaminhado em 12 de maio do mesmo ano à relatora, Senadora Vanessa Grazziottin. 
Após solicitação, o projeto foi encaminhado à Comissão de Ciência, Tecnologia, Inovação, Comunicação e Informática (CCT), em 18 de junho de 2015, sendo designada, aos vinte e três dias do mesmo mês e ano, a relatoria do Senador Randolfe Rodrigues.

Aos dias 11 e 12 de agosto de 2015, foram realizadas audiências públicas com a presença do Conselho de Informações sobre a Biotecnologia - CIB; do Instituto Socioambiental - ISA; de professora da Pontifícia Universidade Católica de São Paulo - PUC/SP; da Associação Brasileira das Indústrias de Alimentação - ABIA; da Comissão Técnica Nacional de Biossegurança - CTNBio; da Escola Nacional de Defesa do Consumidor da Secretaria Nacional do Consumidor do Ministério da Justiça - ENDC/Senacom/MJ, Gabinete da Secretaria de Defesa Agropecuária do Ministério da Agricultura, Pecuária e Abastecimento - SDA/MAPA; da Organização Terra de Direitos; de professor da Universidade de São Paulo - USP; de pesquisadora em Alimentos do Instituto de Defesa do Consumidor - IDEC; do Ministério Público Federal - MPF; da Câmara Interministerial de Agroecologia e Produção Orgânica da Secretaria da Agricultura Familiar do Ministério do Desenvolvimento Agrário Ciapo/SAF/MDA e Superintendente de Correlatos e Alimentos da Agência Nacional de Vigilância Sanitária - ANVISA.

Em 20 de agosto de 2015, o Senador Randolfe Rodrigues apresentou seu relatório contrário ao $\operatorname{PLC~n}^{\circ}$ 34/2015, o qual, em 13 de outubro de 2015, foi apreciado pela Comissão e aprovado conforme apresentado.

Em 05 de novembro de 2015, o projeto segue para a Comissão de Agricultura e Reforma Agrária (CRA). Em 14 de julho de 2016, após tramitação e juntadas de requerimentos, o projeto é distribuído para relatoria do Senador Cidinho Santos, que devolve os autos com parecer favorável à aprovação do projeto, no dia 10 de fevereiro de 2017. Em 21 de junho de 2017, o projeto segue com pedido de vista para a Senadora Regina Sousa, que apresenta seu voto em separado, pela rejeição do projeto em 01 de agosto de 2017. Em 19 de setembro de 2017, o relator apresenta os autos como matéria extrapauta em sessão extraordinária, aprovando-se o relatório com voto divergente da Senadora Regina Sousa.

Em 21 de setembro de 2017, os autos são encaminhados à Comissão de Assuntos Sociais (CAS) e são devolvidos para a relatora Vanessa Grazziottin, em 28 de setembro do mesmo ano. Aos 27 dias do mês de novembro de 2017, a senadora apresenta seu relatório contrário à aprovação do PLC no 34/2015. Em 12 de dezembro de 2017, o Senador Cidinho Santos apresentou voto em separado pela aprovação do projeto. Em 21 de março de 2018, a Comissão aprova o relatório da Senadora Vanessa Grazziottin por nove votos favoráveis e sete votos contra. 
Aos 21 dias do mês de março de 2018, o projeto é encaminhado para a Comissão de Meio Ambiente (CMA), sendo distribuído à relatoria do Senador Cidinho Santos em 23 de março do mesmo ano. Em 05 de abril de 2018, o relator apresenta relatório favorável à aprovação do PLC nº 34/2015, a qual se efetiva na sessão do dia 17 de abril de 2018.

Aos 02 dias do mês de janeiro de 2019, o PLC n. 34/2015 é encaminhado para a Comissão de Transparência, Governança, Fiscalização e Controle e Defesa do Consumidor (CTFC), sendo distribuído à relatoria do Senador Randolfe Rodrigues em 20 de março do mesmo ano. Até o presente momento, os autos continuam sob análise do Senador.

Faz-se mister ressaltar que, durante a tramitação do Projeto de Lei, foram juntadas aos autos manifestações de diversos órgãos, organizações, associações, conselhos e instituições contrárias à aprovação do PLC nº 34/2015.

\section{OS PARECERES FA VORÁVEIS À APROVAÇÃO DO PROJETO}

Conforme se depreende da análise do histórico de tramitação do PLC, foram apresentados, até o presente momento, dois pareceres favoráveis à aprovação da proposta de alteração legislativa, exarados pela Comissão de Meio Ambiente (CMA) e pela Comissão de Agricultura e Reforma Agrária (CRA), ambos sob a relatoria do Senador Cidinho Santos.

Incialmente, cumpre destacar que nos termos do Regimento Interno do Senado Federal, art. 104-B, XVIII, a Comissão de Agricultura e Reforma Agrária (CRA) tem competência para opinar sobre assuntos que digam respeito a políticas de desenvolvimento tecnológico da agropecuária, mediante estímulos fiscais, financeiros e creditícios à pesquisa, ao plantio e à comercialização de organismos geneticamente modificados (OGM).

A CRA salienta que:

a) não existem registros de que a ingestão de alimentos transgênicos cause danos à saúde humana;

b) a transgenia apenas acelera evoluções genéticas, que poderiam levar centenas de anos em processo de seleção natural;

c) os posicionamentos contrários à transgenia resultam de incompreensão sobre a importância e a natureza dos avanços da ciência, por motivos ideológicos e religiosos; d) a Lei de Biossegurança não utiliza o termo transgênico e que sua introdução por meio do PLC pode gerar insegurança jurídica, uma vez que não existe na norma conceito sobre o termo; 
e) é importante estabelecer um limite de tolerância considerado aceitável na composição dos alimentos que contenham transgênicos dada a impossibilidade de segregação total dos produtos agrícolas convencionais ou transgênicos;

f) haverá regulamentação sobre a análise específica dos ingredientes dos alimentos, bem como sobre a fiscalização quanto às regras de embalagem e rotulagem;

g) os alimentos que não contenham OGM's poderão ter essa informação registrada em sua rotulagem;

h) a natureza transgênica do alimento permanecerá sendo informada atendendo ao tamanho mínimo de letra definida no "Regulamento Técnico de Rotulagem Geral de Alimentos Embalados", previsto na Resolução n. 259/2002 da Agência Nacional de Vigilância Sanitária (ANVISA); e, por fim,

i) a alteração legislativa não ofenderá aos direitos dos consumidores, uma vez que a lei manterá a obrigatoriedade da informação clara e ostensiva na embalagem, sobre a eventual natureza transgênica do produto.

Quanto à Comissão de Meio Ambiente (CMA), deve-se mencionar que, nos termos do Regimento Interno do Senado Federal, art. 102-F, V, compete a ela opinar sobre a fiscalização de alimentos, produtos, insumos agrícolas e pecuários, no tocante ao meio ambiente e ao desenvolvimento sustentável.

Em sua análise, a CMA e a CRA afirmam que:

a) não existem estudos que comprovem os malefícios que a ingestão de alimentos transgênicos causa a saúde humana;

b) deve ser estabelecido um limite de tolerância na quantidade de transgênicos na composição do alimento, uma vez que não é possível garantir a total separação dos produtos agrícolas;

c) as informações quanto à composição dos alimentos continuam sendo obrigatórias na rotulagem dos alimentos, respeitando-se, assim, o direito constitucional à informação;

d) a obrigatoriedade da informação passará a constar em lei e não mais em decreto, o que garante maior segurança ao direito do consumidor;

e) os alimentos que não contenham a presença de transgênicos poderão informar o fato na embalagem;

f) a eliminação do símbolo " $\mathrm{T}$ " das embalagens dos produtos não pode ser associada ao desrespeito do Código de Defesa do Consumidor, uma vez que será 
mantida a informação da presença de transgênicos de forma clara e em letras legíveis, não interferindo na qualidade da informação passada ao consumidor; e, por fim,

g) em atenção ao princípio da precaução, o PLC reduziu a um por cento o limite da obrigatoriedade de informar ao consumidor sobre a presença de transgênicos na composição do alimento.

Verifica-se que os argumentos são frágeis, seja no tocante aos argumentos a favor do Projeto, sejam os argumentos legislativos, ou doutrinários.

\section{OS PARECERES CONTRÁRIOS À APROVAÇÃO DO PROJETO}

No que tange às manifestações contrárias à aprovação do projeto, assim como se verificou no item anterior, também foram exarados dois pareceres, provenientes da Comissão de Ciência, Tecnologia, Inovação, Comunicação e Informática (CCT) e da Comissão de Assuntos Sociais (CAS).

O primeiro deles, conforme já mencionado, foi o do Senador Randolfe Rodrigues pela CCT. Cumpre salientar que, nos termos do art. 104-C, VIII, do Regimento Interno do Senado Federal, é competência da CCT opinar sobre assuntos que digam respeito a regulamentação, controle e questões éticas referentes à comunicação.

O relator destacou que:

a) a defesa do consumidor, incluindo seu direito à informação, é princípio constitucional e, portanto, deve ser respeitado, independentemente da presença ou da ausência de riscos à saúde, constituindo crime a sua violação;

b) a questão principal da alteração legislativa diz respeito à análise específica que será utilizada para comprovação da presença de OGM's, uma vez que a identificação da origem transgênica do produto não será mais realizada quanto à matéria-prima utilizada, mas, sim, com base na composição do produto final, sendo necessária a comprovação laboratorial (o que, na legislação atual, não se verifica);

c) com a previsão de exame laboratorial no produto final, o consumidor terá seu direito à informação violado e será ludibriado quanto à composição do alimento, uma vez que não existe possibilidade técnica de se verificar a presença de transgênicos após o processamento da matéria-prima;

d) as pesquisas públicas realizadas demonstram que a maioria da população é contra a referida alteração legislativa; 
e) deve-se dar destaque ao princípio da precaução, uma vez que não existem estudos suficientes para comprovar os efeitos dos alimentos transgênicos sobre o ambiente e a saúde humana, e que, na plantação desses organismos, tem-se aumentado cada vez mais a utilização de agrotóxicos, os quais, comprovadamente, geram danos à saúde humana e ao meio ambiente;

f) a utilização do símbolo "T" não obstaculiza o consumo de alimentos transgênicos e nem abala a credibilidade dos produtos perante os consumidores, conforme comprovado por pesquisas que demonstraram que grande parte da população não conhece o significado do símbolo;

g) existe grande carência de conhecimento dos consumidores sobre o tema, o que é ainda mais agravado com a ausência do rótulo; e, por fim,

h) já foi apontado por especialistas que a cor amarela do símbolo não gera medo nos consumidores, mas, sim, cautela.

O segundo relatório foi exarado pela Senadora Vanessa Grazziottin, na Comissão de Assuntos Sociais (CAS).

Conforme verificado no art. 100, II, do Regimento Interno do Senado Federal, a Comissão de Assuntos Sociais é competente para analisar as questões que envolvam proteção e defesa da saúde.

Em seu relatório, a CAS destacou que:

a) por meio da avaliação de risco, pode ser verificado o impacto que os OGM's causam à saúde humana e, até o presente momento, os riscos estão associados à alergenicidade e a alterações nutricionais e resistência a antibióticos;

b) aparentemente, existe consenso entre os pesquisadores sobre a quantidade insuficiente de conhecimento acumulado sobre como funcionam as toxinas ou as substâncias alergênicas dos produtos modificados, bem como sobre os seus efeitos a longo prazo;

c) o período de observação e estudo é curto quando se fala de danos à saúde a longo prazo;

d) os danos à saúde também se relacionam com o aumento do uso de agrotóxicos, uma vez que, em grande parte, os organismos geneticamente modificados são resistentes aos "venenos agrícolas";

e) deve ser priorizado o princípio da precaução, já que não se tem evidências científicas sobre os riscos diretos ou indiretos dos OGM's para a saúde e para o meio ambiente; 
f) ainda por conta do princípio da precaução, deve-se possibilitar informações amplas para que o consumidor possa escolher sobre o consumo ou não dos alimentos transgênicos; e, por fim,

g) a faculdade da inclusão de informações sobre a ausência de produtos geneticamente modificados na embalagem poderá acarretar dificuldades para os pequenos produtores, uma vez que as análises específicas mencionadas na proposta de alteração onerariam o processo de produção, prejudicando os consumidores que ou ficariam sem a informação ou teriam produtos mais caros.

\title{
4 OS PRINCÍPIOS DO DIREITO À INFORMAÇÃO, DA PRECAUÇÃO E DA LIVRE CONCORRÊNCIA
}

A Constituição Federal possui título expresso sobre a ordem econômica e financeira e, em seu art. 170, dispõe que a ordem econômica é fundada na valorização do trabalho humano e na livre iniciativa, tendo como finalidade assegurar uma existência digna a todos. Por fim, o mesmo artigo destaca que a livre concorrência, a defesa do consumidor e a defesa do meio ambiente constituem princípios que devem ser observados para o alcance do fim previsto.

\begin{abstract}
Art. 170. A ordem econômica, fundada na valorização do trabalho humano e na livre iniciativa, tem por fim assegurar a todos existência digna, conforme os ditames da justiça social, observados os seguintes princípios: I - soberania nacional; II propriedade privada; III - função social da propriedade; IV - livre concorrência; V defesa do consumidor; VI - defesa do meio ambiente, inclusive mediante tratamento diferenciado conforme o impacto ambiental dos produtos e serviços e de seus processos de elaboração e prestação; VII - redução das desigualdades regionais e sociais; VIII - busca do pleno emprego; IX - tratamento favorecido para as empresas de pequeno porte constituídas sob as leis brasileiras e que tenham sua sede e administração no País. Parágrafo único. É assegurado a todos o livre exercício de qualquer atividade econômica, independentemente de autorização de órgãos públicos, salvo nos casos previstos em lei.
\end{abstract}

Nesse sentido Silva (2005, p. 793), ao tratar sobre a livre iniciativa, afirma que:

Será ilegítima, quando exercida com objetivo de puro lucro e realização pessoal do empresário. Daí por que a iniciativa econômica pública, embora sujeita a outros tantos condicionamentos constitucionais, se torna legítima, por mais ampla que seja, quando destinada a assegurar a todos existência digna, conforme os ditames da justiça social. Cumpre, então, observar que a liberdade de iniciativa econômica não sofre compressão só do Poder Público. Este efetivamente o faz legitimamente nos termos da lei, quer regulando a liberdade de indústria e comércio, em alguns casos impondo a necessidade de autorização ou de permissão para determinado tipo de atividade 
econômica, quer regulando a liberdade de contratar, especialmente no que tange às relações de trabalho, mas também quanto à fixação de preços, além da intervenção e comercialização de certos bens. Acontece que o desenvolvimento do poder econômico privado, fundado especialmente na concentração de empresas, é fator de limitação à própria inciativa privada, na medida em que a concentração capitalista impede ou estorva a expansão das pequenas iniciativas econômicas.

E continua Silva (2005, p. 795), a destacar que a livre concorrência "é uma manifestação da liberdade de iniciativa, e, para garanti-la, a Constituição estatui que a lei reprimirá o abuso do poder econômico que vise à dominação dos mercados, à eliminação da concorrência e ao aumento arbitrário dos lucros (art. 173, §4²)".

Percebe-se, então, que os institutos da livre iniciativa e da livre concorrência visam a coibir o abuso de poder econômico capaz de dominar o mercado e eliminar a concorrência. É uma forma de proteger o livre mercado e, consequentemente, os consumidores.

Não se pode ignorar que, em uma sociedade capitalista, a concorrência é ditada pelos detentores do capital; todavia, se a regulamentação estatal econômica da concorrência não consegue ser eficaz, é preciso que não se prejudiquem aqueles que, em condições menos favorecidas de capital, fazem parte do negócio.

Ragazzo (2006, p.86), ao tratar sobre a livre iniciativa e a livre concorrência, afirma:

Num modelo de livre concorrência há maior variedade de produtos por menores preços, com a criação de incentivos para que as empresas aumentem produtividade e introduzam novas tecnologias. A livre concorrência aumenta o bem estar dos consumidores, ao mesmo tempo em que contribui para o desenvolvimento econômico.

E continua Ragazzo (2006, p.86-87):

\begin{abstract}
Dessa forma, o objetivo da livre concorrência é preservar o processo de competição e não os seus competidores. O processo de competição, no modelo concorrencial, é o que possibilita a repartição ótima dos bens dentro da sociedade, contribuindo para a justiça social. Isso não significa que a concorrência não deve ser sopesada com outros interesses, como, por exemplo, a defesa do meio ambiente, a manutenção de empregos, o desenvolvimento sustentável, entre outros. Embora por vezes excludentes entre si, todos esses interesses devem ser ponderados a fim de que o bemestar social seja atingido.
\end{abstract}

Nesse sentido, a alteração legislativa prevista no PLC $n^{\circ} 34 / 2015$, ao incluir o $\S 2^{\circ}$., ao art. 40, da Lei $\mathrm{n}^{\mathrm{0}}$ 11.105/2005, que faculta o registro, nos alimentos que não contenham OGM's, da rotulagem "livre de transgênicos", mas desde que comprovada tal ausência na composição, após análise específica, acarreta dificuldades aos pequenos produtores e empresários, que terão que arcar com os custos de análises específicas de seus produtos. Não é difícil afirmar que, 
quanto mais custos para a produção dos alimentos, maior será o valor a ser desembolsado pelo consumidor, o que atentará contra a sua vida, pois ninguém vive sem alimentar-se.

A necessidade de realizar a análise específica dos produtos e a certeza do aumento dos custos de produção dos pequenos produtores/empresários vão de encontro ao posicionamento do Governo Federal exarado no Documento de Contribuição Brasileira à Conferência Rio+20 (2011, p.8):

\begin{abstract}
O Estado brasileiro busca consolidar o direito à alimentação. O grande desafio é assegurar que as políticas públicas atuem de forma integrada, intersetorial, viabilizando ações que vão desde a produção de alimentos - onde o segmento da agricultura familiar deve ser incluído e valorizado - até o consumo de alimentos. A partir desta integração será possível enfrentar os desafios da conservação ambiental, da adaptação à mudança do clima e da busca por maior justiça social. Como todas as demais políticas públicas, aquelas voltadas à segurança alimentar e nutricional não podem prescindir da ampla participação social. $O$ Brasil acredita que a participação representa condição sine qua non para o desenvolvimento econômico e social com proteção ambiental, em âmbito nacional e internacional. (grifou-se)
\end{abstract}

Poder-se-ia afirmar, aqui, que o parágrafo a ser acrescentado no art.40 da Lei de Biossegurança apenas faculta ao produtor o registro de tal informação e que, caso não seja realizado, não haverá óbices para a comercialização do alimento. $\mathrm{O}$ argumento é verdadeiro; todavia, a ausência dessa informação na rotulagem de alimentos orgânicos que se misturam em prateleiras juntamente com produtos contendo organismos geneticamente modificados impossibilitará que o consumidor escolha pelo produto "livre de transgênicos" nos dizeres da proposta.

Sendo assim, resta difícil acreditar que empresas preocupadas em utilizar apenas produtos sem modificação genética na composição de seus alimentos não farão menção de tal fato na embalagem. Parece estranho, ainda, "impor" àquele que não procedeu a qualquer modificação no DNA de seus alimentos e que busca não utilizar os alimentos transgênicos a necessidade de informar tal fato. Parece-nos bem mais claro e óbvio que tal obrigação recaia sobre aqueles que escolhem utilizar ou produzir os alimentos geneticamente modificados.

Ainda nesses termos, deve-se mencionar a Lei no $12.529 / 2011$, que prevê:

Art. $1^{\circ}$ Esta Lei estrutura o Sistema Brasileiro de Defesa da Concorrência - SBDC e dispõe sobre a prevenção e a repressão às infrações contra a ordem econômica, orientada pelos ditames constitucionais de liberdade de iniciativa, livre concorrência, função social da propriedade, defesa dos consumidores e repressão ao abuso do poder econômico. Parágrafo único. A coletividade é a titular dos bens jurídicos protegidos por esta Lei. 
Diante de tantos normativos legais e constitucionais, não se pode ignorar que a vontade constitucional e legal é de proteção da livre iniciativa e da livre concorrência, beneficiando a coletividade.

Ainda quanto à “análise específica” mencionada no PLC no 34/2015, é necessário entender em que esta consistiria, e como e por quem seria realizada, sem considerar, nessa análise, os custos já mencionados acima.

Ao tratar sobre o tema, o parecer da Comissão de Agricultura e Reforma Agrária destaca:

\begin{abstract}
Espera-se que o regulamento que tratará da análise específica mencionada no artigo proposto a atribuirá à competência de órgãos públicos de vigilância sanitária, que atuarão por meio de amostragens da matéria- prima utilizada pela agroindústria de alimentos. Isso é importante, uma vez que o custo da análise laboratorial é elevado e a sua realização demandará esforço orçamentário do Poder Público. Alternativamente, o Poder Público poderá estabelecer taxas a serem pagas pela indústria de alimentos, para custear as análises em laboratórios privados credenciados. Acreditamos que o regulamento também tratará da frequência com que tais análises deverão ser realizadas, não sendo cabível que todas as partidas e cargas de alimentos ou de matéria-prima a ser utilizada na sua fabricação sejam, necessariamente, analisadas quanto à ocorrência de transgênicos. É a fiscalização por amostras que deve avaliar se os fornecedores de alimentos ou matéria-prima para sua fabricação estão cumprindo a legislação quanto à rotulagem e embalagem.
\end{abstract}

Percebe-se que nem mesmo a Comissão favorável à aprovação do projeto é capaz de detalhar qual seria a maneira pela qual os alimentos seriam testados, com que frequência, sob quais custos e por quais autoridades técnicas, o que demonstra a grande insegurança que a referida análise causará.

Quanto ao princípio da precaução, como é sabido, foi consignado como princípio na Conferência das Nações Unidas para o Meio ambiente e o Desenvolvimento, em 1992. O princípio tem como finalidade proteger o meio ambiente quando não exista certeza científica sobre a possível ocorrência de danos graves e irreversíveis gerados por determinadas ações.

Pozzetti (2014, p.105) afirma:

Do latim precautio-onis, a precaução é uma cautela antecipada; ou seja, uma ação antecipada diante do risco ou do perigo. Assim, o mundo da precaução caracteriza-se por ser um mundo onde há uma interrogação, ou seja, uma dupla fonte de incertezas: o perigo em si mesmo e a ausência do conhecimento científico sobre o perigo. Nascida da diferença temporal entre a necessidade imediata de ação e o momento onde nossos conhecimentos científicos vão modificar-se, a Precaução visa gerenciar esta espera da informação adequada. A ideia deste princípio encontra respaldo no famoso ditado popular: "melhor prevenir do que remediar. 
É claro, portanto, que é por meio do princípio da precaução que se deve tomar cautelas para evitar possíveis reflexos que a utilização dos alimentos transgênicos, objeto do estudo em questão, podem causar. Considerando que não se discutem aqui quais os benefícios ou malefícios que podem estar presentes nos OGM's, o que se quer demonstrar é que deve ser mantido um processo democrático para que se garanta o direito ao consentimento informado.

Durante as discussões estabelecidas nos pareceres dos senadores, muito se falou sobre as certezas e incertezas, sobre os estudos, ou a falta deles, para comprovarem os danos, riscos ou malefícios que a produção e a ingestão dos alimentos transgênicos podem causar ao meio ambiente e à saúde humana.

Nesse sentido, Câmara et al. (2009, p. 671 e 672) realizaram pesquisas sobre as produções científicas relacionadas à saúde pública no que tange aos organismos geneticamente modificados e destacam:

\begin{abstract}
A busca por intermédio dos descritores mencionados resultou na localização de 716 estudos, dos quais 80 eram artigos e 636, teses e dissertações. O período da pesquisa foi de 1987 a 2008, e verificou-se que a maior parte das publicações ocorreu a partir de 1998 (aproximadamente 95\%), em especial em 2007, ano que compreendeu 13,2\% das publicações (94 estudos). A literatura científica sobre transgênicos é ampla e diversa. Tange assuntos como rotulagem, direito do consumidor, biossegurança, experimentos em laboratórios, produção, comercialização e liberação comercial, riscos e benefícios oriundos dessa tecnologia. Apesar do grande número de referências reunidas sobre o tema, apenas oito estudos abordam especificamente a (in)segurança alimentar dos alimentos geneticamente modificados. [...] Estudo semelhante ao exposto neste artigo foi realizado por Domingo (2007), que fez uma revisão da literatura no portal Medline. Nela foram identificadas mais de cinco mil referências a transgênicos, entretanto quanto à avaliação de risco - objetivo principal - localizaramse apenas 29 escritos. O autor conclui que a tecnologia transgênica é nova e que os cientistas ainda não têm um conhecimento completo sobre ela. Afirma ainda que são necessários mais estudos científicos e investigações para garantir que a ingestão de alimentos geneticamente modificados não apresenta riscos para a saúde da população e o meio ambiente.
\end{abstract}

No mesmo sentido, Almeida Jr e Mattos (2005, p. 3) mencionam:

Duzentos e seis renomados cientistas assinaram uma carta aberta aos governos do mundo pedindo a retirada de todos os alimentos geneticamente modificados do mercado, pedido esse feito com base na insuficiência dos testes de segurança a que eles foram submetidos (PHYSICIANS AND SCIENTISTS FOR RESPONSIBLE APPLICATION OF SCIENCE AND TECHNOLOGY - PSRAST, 2004).

É de se destacar que não existem estudos suficientes e conclusivos sobre as consequências causadas pelos OGM's. É exatamente essa a razão que deve ser considerada para que se evite que os alimentos transgênicos, uma vez que sua produção e comercialização já está liberada no país, sejam consumidos sem que a população tenha conhecimento do que está 
ingerindo. Não é aceitável que se impute ao meio ambiente e ao consumidor riscos desconhecidos à sua conservação e à saúde de forma obscura.

Também não se pode defender que não seja necessária a observância do princípio da precaução por não haver comprovação dos riscos que tais alimentos podem causar, até mesmo porque, é esse o motivo que leva à necessidade de sua utilização.

Cumpre ressaltar que se for realizada uma análise das decisões legislativas e políticas, ainda que sem métodos científicos, resta claro que muitos posicionamentos, para não dizer a maioria ou todos, são adotados com objetivos políticos e comerciais que abarcam interesses de uma pequena parcela da população.

Já no que tange à defesa do consumidor, deve-se mencionar que ela está prevista expressamente no art. $5^{\circ}$., XXXII, CF/88, além do art. 170, e o inciso XIV do artigo $5^{\circ}$. menciona ainda que é assegurado a todos o direito à informação, direito esse inerente à defesa do consumidor.

Nesse mesmo sentido, o Código de Defesa do Consumidor - CDC - estabelece, em seu art. $6^{\circ}$ :

Art. $6^{\circ}$. São direitos básicos do consumidor: I - a proteção da vida, saúde e segurança contra os riscos provocados por práticas no fornecimento de produtos e serviços considerados perigosos ou nocivos; II - a educação e divulgação sobre o consumo adequado dos produtos e serviços, asseguradas a liberdade de escolha e a igualdade nas contratações; III - a informação adequada e clara sobre os diferentes produtos e serviços, com especificação correta de quantidade, características, composição, qualidade, tributos incidentes e preço, bem como sobre os riscos que apresentem; [...]

O CDC estabelece ainda:

\begin{abstract}
Art. 31. A oferta e apresentação de produtos ou serviços devem assegurar informações corretas, claras, precisas, ostensivas e em língua portuguesa sobre suas características, qualidades, quantidade, composição, preço, garantia, prazos de validade e origem, entre outros dados, bem como sobre os riscos que apresentam à saúde e segurança dos consumidores. Parágrafo único. As informações de que trata este artigo, nos produtos refrigerados oferecidos ao consumidor, serão gravadas de forma indelével.
\end{abstract}

Dessa forma, é necessário que sejam evidenciados três aspectos relacionados ao direito à informação e à proteção do consumidor abarcados pelo PLC n ${ }^{\circ}$ 34/2015 e mencionados nos relatórios apresentados: a) a retirada do símbolo " $\mathrm{T}$ " das embalagens dos alimentos transgênicos; b) a forma como será expressa na embalagem a presença de OGM's nos produtos; e c) a impossibilidade de verificação da presença de transgênicos em alimentos processados e 
a consequente privação da informação sobre a utilização de matéria-prima transgênica e indução do consumidor a erro.

Primeiramente, quanto à retirada do símbolo " $\mathrm{T}$ " das embalagens dos alimentos transgênicos, a CMA favorável à alteração legislativa, $(2018$, p.6) afirma que não haverá qualquer tipo de prejuízo ao consumidor, uma vez que "pesquisa realizada em 2014 pela Associação Brasileira das Indústrias de Alimentos, em parceria com o instituto IPSOS, revelou que $69 \%$ dos entrevistados ignora o significado do símbolo " $T$ ", e que $14 \%$ o confunde com um sinal de trânsito". Pelo entendimento do relator, a retirada do símbolo não interferiria na qualidade da informação prestada ao consumidor e seria até benéfica, já que constaria uma eficiência informativa garantida por meio de mensagem escrita de identificação clara.

A Comissão de Reforma Agrária acrescenta, aos argumentos levantados, o fato de que alimentos que contém glúten, lactose, gorduras trans, ou sal ou açúcar em quantidades que causem danos à saúde não constarem das embalagens símbolos que alertem para tal fato.

Conforme a Lei $\mathrm{n}^{\mathrm{o}}$ 10.674/2003, a presença de glúten em alimentos deve ser informada sem a necessidade de símbolo que a represente. Contrariamente do que afirma o relator da CMA e da CRA, a situação não é similar. No que diz respeito a alimentos com glúten, por exemplo, a ausência de exigência legal de rotulagem com símbolos e informações mais claras e precisas ao consumidor não pode ser utilizada como razão para que haja um retrocesso na legislação aplicada a outros alimentos.

Nesse sentido, a Senadora Regina Sousa (2015, p.6) se manifestou em voto divergente apresentado na Comissão de Agricultura e Reforma Agrária:

\footnotetext{
No entanto, utilizar uma omissão legislativa como justificativa para outra é pouco razoável. Não é porque produtos à base de glúten ou lactose não são rotulados com símbolo de fácil identificação que produtos à base de transgênicos não o devam ser. É justamente o contrário. Porque produtos à base de transgênicos são e devem ser rotulados com símbolo de advertência de fácil visualização, essa exigência deve ser estendida a produtos à base de glúten ou lactose. Por isso, em vez de aprovar um projeto de lei que acabe com essa exigência em relação a transgênicos, poderíamos apresentar, juntamente com o Senador Cidinho Santos, uma proposição legislativa que obrigue a presença de um símbolo de fácil identificação nos rótulos de produtos à base de glúten ou lactose. Essa medida certamente evitará diversos casos de alergia e intolerância alimentar por glúten ou lactose que atualmente ocorrem, apesar da informação escrita, justamente porque a linguagem visual, acompanhada de campanhas informativas, é muito mais clara, eficiente e fácil de ser compreendida.
}

Razão assiste à senadora. Não é correto com o titular do direito de informação que aqueles que devam ser os representantes do povo e dos Estados na elaboração das leis, se 
utilizem de falhas ou lacunas que deveriam ser preenchidos por eles próprios, para retirarem um bem já alcançado.

Rothenburg (2012, p.247), em Colóquio Internacional sobre o Princípio da Proibição de Retrocesso Ambiental realizado pelo Senado Federal, afirma que o princípio do não retrocesso é uma conquista que não deve ser regredida:

O principio do não retrocesso, segundo o qual o nível de promoção e proteção de um direito não admite diminuição ou enfraquecimento, e uma conquista já sedimentada da teoria dos direitos fundamentais e não lhe prestar a devida atenção constitui por si um retrocesso.

A Organização das Nações Unidas - ONU, na Agenda 2030 para o Desenvolvimento Sustentável, adotou como $2^{\circ}$ objetivo o de acabar com a fome, alcançar a segurança alimentar e a melhoria da nutrição e promover a agricultura sustentável:

2.c Adotar medidas para garantir o funcionamento adequado dos mercados de commodities de alimentos e seus derivados, e facilitar o acesso oportuno à informação de mercado, inclusive sobre as reservas de alimentos, a fim de ajudar a limitar a volatilidade extrema dos preços dos alimentos. (grifou-se)

O mesmo diploma dispôs, nos considerandos de seu objetivo 12, "assegurar padrões de produção e de consumo sustentáveis: "12.8 Até 2030, garantir que as pessoas, em todos os lugares, tenham informação relevante e conscientização para o desenvolvimento sustentável e estilos de vida em harmonia com a natureza" (grifou-se)

Percebe-se que o caminho internacional, no qual o Brasil se insere, é o de privilegiar o acesso à informação em relação ao consumo, à saúde e à alimentação, de forma que não há razões para que argumentos pueris, como o do não conhecimento do símbolo $T$ pela população, sejam utilizados, de modo a se reduzir o acesso à informação já conquistado. Resta claro que, se o cidadão não conhece o significado de um símbolo que identifica um alimento sobre o qual não se tem qualquer tipo de certeza sobre riscos, o mais correto seria que a ele fosse concedido conhecimento para exercer a sua escolha, e não que dele fosse retirada a informação.

A superveniência de legislações que importem retrocesso e configurem atrasos não podem ser aceitas, como se delas não irrompessem reflexos à vida da população. Por essa razão, é necessário que se restrinjam as normas que violem, diminuam ou esvaziem direitos fundamentais.

Quanto ao segundo aspecto, a forma como será expressa na embalagem a presença de OGM's, o PLC n. 34/2015 acrescenta os $\S \S^{\circ}$ e $3^{\circ}$ ao art. 40 da Lei n. 11.105/2015: 
$\S 1^{\circ}$. A informação estabelecida neste artigo deve constar nos rótulos dos alimentos embalados na ausência do consumidor, bem como nos recipientes de alimentos vendidos a granel ou in natura diretamente ao consumidor, devendo ser grafada, em destaque, de forma legível, utilizando-se uma das seguintes expressões, conforme o caso, "(nome do produto) transgênico" ou "contém (nome do ingrediente) transgênico". [...] $\S 3^{\circ}$. A informação de que trata o $\S 1^{\circ}$. deverá atender ao tamanho mínimo de letra definida no Regulamento Técnico de Rotulagem Geral de Alimentos Embalados.

O ordenamento jurídico brasileiro contempla normas que tratam objetivamente sobre as embalagens e rotulagens dos alimentos. Um importante normativo é a Resolução de Diretoria Colegiada (RDC) n. 259/2002 da Agência Nacional de Vigilância Sanitária - ANVISA. Tal normativo aprova o Regulamento Técnico sobre Rotulagem de Alimentos Embalados, aplicável à rotulagem de todo alimento comercializado, independentemente de sua origem.

A Resolução estabelece ainda diversas definições aplicáveis ao tema:

2.1. Rotulagem: É toda inscrição, legenda, imagem ou toda matéria descritiva ou gráfica, escrita, impressa, estampada, gravada, gravada em relevo ou litografada ou colada sobre a embalagem do alimento. 2.2. Embalagem: É o recipiente, o pacote ou a embalagem destinada a garantir a conservação e facilitar o transporte e manuseio dos alimentos. [...] 2.3. Alimento embalado: É todo o alimento que está contido em uma embalagem pronta para ser oferecida ao consumidor. 2.4. Consumidor: É toda pessoa física ou jurídica que adquire ou utiliza alimentos. 2.5. Ingrediente: É toda substância, incluídos os aditivos alimentares, que se emprega na fabricação ou preparo de alimentos, e que está presente no produto final em sua forma original ou modificada. 2.6. Matéria-prima: É toda substância que para ser utilizada como alimento necessita sofrer tratamento e ou transformação de natureza física, química ou biológica. [...] 2.8. Alimento: É toda substância que se ingere no estado natural, semi-elaborada ou elaborada, destinada ao consumo humano, incluídas as bebidas e qualquer outra substância utilizada em sua elaboração, preparo ou tratamento, excluídos os cosméticos, o tabaco e as substâncias utilizadas unicamente como medicamentos.

Tais conceitos estão diretamente ligados à discussão sobre a rotulagem dos organismos geneticamente modificados. A regulamentação da rotulagem dos alimentos oferecidos ao consumidor é de grande relevância. É por meio dessa inscrição que informações sobre ingrediente, matéria-prima e identidade de produtos transgênicos podem ser conhecidas, que se reforça a segurança alimentar e que se garante a qualidade dos alimentos oferecidos ao consumidor, possibilitando-se a análise da procedência e a rastreabilidade dos produtos.

Nesse sentido, Pozzetti (2014, p. 110) enumera como principais objetivos do rótulo “1) assegurar o fornecimento de informações adequadas sobre a saúde e segurança; 2) proteger consumidores de indústrias de embalagens fraudulentas e ilusórias; e, 3 ) promover concorrência justa e a comercialização do produto" e finaliza afirmando "Assim, os rótulos podem gerar 
efeitos que vão além do mero fornecimento de informações até a função de educar e alterar comportamentos".

Os pareceres favoráveis à aprovação do $\mathrm{PLC} \mathrm{n}^{\circ} 34 / 2015$ destacam que o $\$ 1^{\circ}$. proposto ao art. 40 da Lei de Biossegurança obrigam a grafia de expressões “(nome do produto) transgênico" ou "contém (nome do ingrediente) transgênico" nos rótulos dos produtos que contenham ou sejam produzidos a partir de OGM. Sugerem ainda que, por essa razão, o direito à informação do consumidor não seria violado. A afirmação teria grande valor não fosse a disposição prevista no §3o. proposto no projeto de lei. Conforme já mencionado, o referido parágrafo determina que a inscrição relacionada à presença de OGM deverá atender ao tamanho mínimo de letra definida no Regulamento Técnico de Rotulagem Geral de Alimentos Embalados.

O RDC n 259/2002 - ANVISA, por sua vez, dispõe que "o tamanho das letras e números da rotulagem obrigatória, exceto a indicação dos conteúdos líquidos, não pode ser inferior a $1 \mathrm{~mm}$ ". A necessidade de rotulagem com informações corretas, claras, precisas e ostensivas previstas no CDC de certo não é satisfeita com indicações de $1 \mathrm{~mm}$ nas embalagens dos produtos, não atendendo à premissa básica de que o consumidor tem o direito de saber o que está comprando e realizar uma escolha consciente.

Quanto à terceira disposição pertinente ao direito à informação, resta argumentar sobre o que seria considerado como o aspecto mais grave da alteração legislativa. O PLC n $34 / 2015$ dispõe em seu caput:

\begin{abstract}
Art. 40. Os rótulos dos alimentos e dos ingredientes alimentares destinados ao consumo humano ou animal, oferecidos em embalagem de consumo final, que contenham ou sejam produzidos a partir de OGM ou derivados com presença superior a $1 \%$ (um por cento) de sua composição final, detectada em análise específica, conforme regulamento, deverão informar ao consumidor a natureza transgênica do alimento.
\end{abstract}

Especificamente quanto à rotulagem de alimentos transgênicos, o ordenamento brasileiro já conta com normativo. O Decreto $n^{\circ} 4.680 / 03$ regulamentou a rotulagem desses alimentos e o direito à informação:

Art. $2^{\circ}$. Na comercialização de alimentos e ingredientes alimentares destinados ao consumo humano ou animal que contenham ou sejam produzidos a partir de organismos geneticamente modificados, com presença acima do limite de um por cento do produto, o consumidor deverá ser informado da natureza transgênica desse produto. 
Da leitura do artigo, percebe-se que o percentual mencionado como limite a partir do qual deve haver menção da presença de OGM no rótulo do produto é o mesmo apresentado na sugestão da nova redação do caput do art. 40 da Lei $n^{\circ} 11.105 / 2005$, previsto no PLC $n^{\circ}$ 34/2015. A diferença entre os dispositivos é sútil, mas existe e tem grandes consequências práticas.

Detalhando-se o disposto no Decreto, verifica-se que, na comercialização de alimentos que sejam produzidos com presença de OGM acima de um por cento do produto, tal informação deve constar no rótulo. Já a nova redação do caput do art. 40 da Lei n. 11.105/2005 passará a mencionar que a referida menção só será necessária em rótulos de alimentos que sejam produzidos a partir de OGM com presença superior a um por cento de sua composição final, detectada em análise específica.

A literalidade do caput do artigo 40 leva a crer que não haverá restrição de informação acerca da presença de organismos geneticamente modificados, mas que haverá apenas limitação da quantidade que é aceita como possível, sem haver necessidade de menção. Assim, entendese que apenas aqueles produtos contendo quantidade inferior a $1 \%$ de matéria prima transgênica é que estarão isentos de atender à especificação de sua composição transgênica.

Infelizmente, tal interpretação é inocente e equivocada. A gravidade da alteração reside na metodologia a ser utilizada na detecção desses OGM's. Tendo em vista que a análise deverá ser realizada no produto final, ou seja, após o organismo ser modificado e processado, na prática não será possível identificar qualquer material transgênico do produto.

Em Nota Técnica apresentada ao Senado Federal, o Instituto Brasileiro de Defesa do Consumidor - IDEC (20015, p.5) destacou a gravidade da modificação ora em análise:

Segundo a sistemática atualmente em vigor, disciplinada pela atual redação do artigo 40 da Lei n. 11.105/2005, pelo Decreto n. 4.680/2003 e pela Portaria do Ministério da Justiça n. 2.658/2003, a identificação da origem transgênica é realizada com base na matéria-prima utilizada na composição do produto final, isto é, no início do processo produtivo. Assim, no sistema atual, basta que determinada espécie transgênica tenha sido utilizada para que advenha a necessidade de rotulagem do produto acerca da presença de OGM. A lógica é simples: havendo matéria-prima transgênica, deverá ocorrer a rotulagem. Observe-se que, dada a facilidade de se identificar a presença de OGM na matéria-prima utilizada no produto, não há necessidade de qualquer comprovação laboratorial. Já pela proposta contida no PL n. 4.148/2008, a identificação da origem transgênica seria realizada no próprio produto final, através de análise laboratorial. A identificação, portanto, não mais seria realizada com base na matéria-prima, mas no próprio produto acabado, na última fase do processo produtivo, por meio da tal "análise específica" Na prática, como a maior parte dos alimentos que contém OGM em sua constituição são (ultra) processados (como óleos e margarinas, por exemplo), a detecção da origem transgênica não será possível de ser realizada. Com isso, a matéria-prima poderá ser $100 \%$ transgênica, mas, em função do processo industrial de fabricação do alimento, este não mais poderá ser identificado como produto de um OGM, dada 
a impossibilidade de se detectar o DNA da matéria-prima transgênica.

Deve-se salientar que adotar uma sistemática de verificação de elementos transgênicos nos produtos posteriormente à sua produção vai de encontro a um sistema já consolidado e claro de informações fornecidas ao consumidor.

Maria Clara Coelho Câmara et al. (2009, p. 673) destacam:

\begin{abstract}
A adoção do critério da ES pressupõe também ignorar os mecanismos de segregação e preservação da identidade, uma vez que, sob essa ótica, tanto os alimentos naturais seriam iguais aos geneticamente modificados. Em 2000, a descoberta de um produto contaminado com uma variedade de milho Bt da Aventis nos EUA - que não havia sido aprovada para consumo humano - colocou a indústria biotecnológica na defensiva (Tokar, 2001). Os consumidores perceberam que estavam expostos a um risco fora de seu controle, e evidenciou-se a importância de estabelecer mecanismos de segregação entre colheitas geneticamente modificadas e não modificadas. Uma das medidas tomadas foi a rotulagem dos alimentos. (gn)
\end{abstract}

Tal mudança tem grande relevância, já que, atualmente, a necessidade da informação de presença de transgênico na rotulagem se baseia na matéria-prima utilizada.

Dada a impossibilidade técnica de se verificar a presença ou não de matéria-prima provida de transgênicos por meio da análise específica realizada no produto final, na prática, a grande maioria dos produtos de origem transgênica não contarão que essa informação em sua embalagem, ainda que a quantidade utilizada seja muito superior ao limite de um por cento determinado na legislação. Portanto, o provável resultado da aprovação do PLC será a ocultação da informação, violando-se direitos fundamentais previstos constitucionalmente.

\title{
CONCLUSÃO
}

A problemática que envolveu esta pesquisa foi a de analisar o PL n ${ }^{\circ} 13465 / 2015$ e verificar se o mesmo traz um plus ou retrocesso ambiental e consumerista. Os objetivos foram atingidos na medida em que se analisou os pareceres emanados das Comissões do Senado Federal, destacando os argumentos favoráveis e contrários defendidos por cada uma delas, no que tange à proposta de alteração da Lei $\mathrm{n}^{\circ}$ 11.105/2005, Lei de Biossegurança e verificar de que forma eles estariam contribuindo.

O estudo se propôs, também, a verificar quais as possíveis consequências que a referida alteração poderia ocasionar às pequenas empresas e aos pequenos produtores e quais 
os direitos dos consumidores seriam ou não violados, especialmente no que tange aos princípios da informação, da precaução e da livre concorrência.

Observou-se que os pareceres das Comissões do Senado Federal focaram suas análises em pontos específicos: a) violação ou não do direito à informação do consumidor pela retirada do símbolo "T"; b) violação ou não do direito à informação do consumidor pela maneira como será realizada a rotulagem; c) violação ou não do direito à informação do consumidor pela impossibilidade de verificação da presença de transgênicos em alimentos processados; d) violação ou não do princípio da concorrência no que tange à atividade dos pequenos produtores/empresários; e) violação do princípio da precaução.

Conclui-se que não foi demonstrado nenhum argumento que comprove que a modificação da Lei de Biossegurança garantirá a observância aos princípios da precaução, do direito à informação do consumidor e da livre iniciativa e concorrência por parte das grandes empresas produtoras de alimentos transgênicos. Ao contrário, as alegações dos pareceres favoráveis demonstraram que não se está considerando a vontade popular de manutenção de todas as formas de informação nos rótulos dos alimentos, ou a proteção do pequeno produtor/empresário, ou, ainda, a proteção do meio ambiente e da saúde humana, mas tãosomente os interesses econômicos e políticos das grandes empresas.

Por fim, conclui-se que para que haja uma real observância dos preceitos constitucionais e dos clamores da sociedade, a decisão mais acertada do Senado Federal seria a rejeição do Projeto de Lei da Câmara n. 34/2015, por contrariar diretamente direitos individuais e coletivos e penalizar os agricultores e empresas alimentícias que escolham por não produzir alimentos com matéria-prima transgênica.

\section{REFERÊNCIAS}

ALMEIDA JR, Antonio Ribeiro de; MATTOS, Zilda Paes de Barros. Ilusórias sementes. Ambient. soc., Campinas , v. 8, n. 1, p. 101-120, Jan. 2005. Disponível em http://www.scielo.br/scielo.php?script=sci_arttext\&pid=S1414-

753X2005000100007\&lng=en\&nrm=iso. Acesso em: 24 de maio de 2019.

BITTAR, Eduardo C. B. Metodologia da Pesquisa Jurídica: teoria e prática da monografia para os cursos de Direito. 16 ed. São Paulo: Saraiva, 2019.

BRASIL. Agência Nacional de Vigilância Sanitária. Resolução da Diretoria Colegiada n. 259/2002. Brasília: Agência Nacional de Vigilância Sanitária, 2002. 
- Congresso. Comissão de Ciência, Tecnologia, Inovações, Comunicação e Informática. Relatório, conclusões e recomendações. Relator Randolfe Rodrigues. Brasília, DF: Senado Federal, Coordenação de Publicações, 2015.

Congresso. Comissão de Agricultura e Reforma Agrária. Relatório, conclusões e recomendações. Relator Cidinho Santos. Brasília, DF: Senado Federal, Coordenação de Publicações, 2017.

Congresso. Comissão de Assuntos Sociais. Relatório, conclusões e recomendações. Relatora Vanessa Grazziottin. Brasília, DF: Senado Federal, Coordenação de Publicações, 2018.

Congresso. Comissão de Meio Ambiente. Relatório, conclusões e recomendações. Relator Cidinho Santos. Brasília, DF: Senado Federal, Coordenação de Publicações, 2018.

Federal. 2019.

Congresso. Regimento Interno: Resolução no 93, de 1970. Brasília: Senado Constituição da República Federativa do. Congresso Nacional, Brasília, 1988.

Decreto no 4.680/2003. Congresso Nacional, Brasília, 2003.

Lei Federal nº 8.078/1990. Congresso Nacional, Brasília, 1990.

Lei Federal n 10.674/2003. Congresso Nacional, Brasília, 2003.

Lei Federal $\mathbf{n}^{\mathbf{0}}$ 11.105/2005. Congresso Nacional, Brasília, 2005.

Lei Federal $\mathbf{n}^{\mathbf{0}}$ 12.529/2011. Congresso Nacional, Brasília, 2011.

CAMARA, Maria Clara Coelho et al. Transgênicos: avaliação da possível (in)segurança alimentar através da produção científica. Hist. cienc. saude-Manguinhos, Rio de Janeiro , v. 16, n. 3, p. 669-681, Sept. 2009 . Disponível em: http://www.scielo.br/scielo.php?script=sci_arttext\&pid=S0104-

59702009000300006\&lng=en\&nrm=iso. Acesso em: 24 de maio de 2019.

NAÇÕES UNIDAS NO BRASIL. A Agenda 2030 para o Desenvolvimento Sustentável. Disponível em: https://nacoesunidas.org/pos2015/agenda2030. Acesso em: 29 de maio de 2019.

POZZETTI, Valmir César e CAMPOS, Jalil Fraxe. ICMS Ecológico: Um desafio à Sustentabilidade Econômico Ambiental no Amazonas. Revista jurídica Unicuritiba. Vol 2, n. 47, ISSN 2316-753X. DOI: 10.6084/m9.figshare.5186836, Curitiba. Disponível in: http://revista.unicuritiba.edu.br/index.php/RevJur/article/view/2035/1314, consultada em 02 jun 2019.

POZZETTI, Valmir César. Alimentos transgênicos e o direito do consumidor à informação. Revista Jurídica Unicuritiba, Curitiba, v.3, n.36, p. 103-131, 2014. Disponível em: http://revista.unicuritiba.edu.br/index.php/RevJur/article/view/993 Acesso em: 24 de maio de 2019. 
PRADANOV, Cléber Cristiano; FREITAS, Emani César de. Metodologia do trabalho científico: métodos e técnicas da pesquisa e do trabalho acadêmico. 2. Ed. Novo Hamburgo: Feevale, 2013.

RAGAZZO, Carlos Emmanuel Joppert. Notas Introdutórias sobre o princípio da livre concorrência. Scientia Juris. Londrina, v. 10, p. 83-96, 2006. Disponível em: http://www.uel.br/revistas/uel/index.php/iuris/article/view/4110/3538 Acesso em: 28 de maio de 2019.

RIO +20. Documento de Contribuição Brasileira à Conferência Rio+20. Brasília, 2011. Disponível em http://www.rio20.gov.br/documentos/contribuicao-brasileira-a-conferencia-rio20/at_download/contribuicao-brasileira-a-conferencia-rio-20.pdf Acesso em 29 de maio de 2019

ROTHENBURG, Walter Claudius. Não retrocesso ambiental: direito fundamental e controle de constitucionalidade. O princípio da Proibição de retrocesso ambiental. In: COLÓQUIO INTERNACIONAL SOBRE O PRINCÍPIO DA PROIBIÇÃO DE RETROCESSO AMBIENTAL. Brasília, Senado Federal, 2012.

SILVA, José Afonso da. Curso de Direito Constitucional Positivo. 25. ed. rev. atual. São Paulo: Malheiros, 2005. 